\title{
EFFECTIVENESS OF CONSUMER PERCEPTION ON FLAT PURCHASE INTENTION IN CHENNAI
}

\author{
Dr. S. Thirunavukarasu $1 \bowtie$ \\ ${ }^{1}$ Assistant Professor, Department of Business Administration Government Arts and Science College, Valparai, \\ India.
}

Received 4 September 2021

Accepted 16 September2021

Published 30 September2021

\section{CorrespondingAuthor}

Dr. S. Thirunavukarasu, assistantprofessor.au@gmail.com

DOI

10.29121/granthaalayah.v9.i9.2021. 4151

Funding: This research received no specific grant from any funding agency in the public, commercial, or not-for-profit sectors.

Copyright: (C) 2021 The Author(s). This is an open access article distributed under the terms of the Creative Commons Attribution License, which permits unrestricted use, distribution, and reproduction in any medium, provided the original author and source are credited.

\section{ABSTRACT}

One of the basic necessities of every human being is shelter. Every individual seeks for a better place to fulfil this necessity. The sector of real estate is the one which helps the individuals to fulfil the need for a home for living. The real estate business helps to build houses, office buildings and other structures according to the needs and requirements of the people. The sector of real estate business is fast growing in developing countries like India, because of huge level of population, increased number of nuclear families and also because of the enhanced levels of income. The main aim of the study is to explore the effect of the perception of the consumers on the purchase intention of the consumers regarding apartments. The study is done among the customers of Chennai. Respondents are selected through simple random sampling. The data needed for the study is collected through a questionnaire and analysis is done using regression. Findings of the study reveal that the purchase intention was highly influenced by the consumer perception.

Keywords: Consumer Perception, Apartment Culture, Flat Purchase, Purchase Intentions

\section{INTRODUCTION}

According to Maclennan (2002), the housing is featured with a lot of attributes. Many of such attributes are the consequence of the internal features and external features of the house itself like the. The internal features include the availability of the rooms. The external features include ease of accessibility of the utilities, facilities, services provided, location and so on Balathandayutham and Sritharan (2012a), Balathandayutham and Sritharan (2012b), Balathandayutham and Sritharan (2012c), Balathandayutham and Sritharan (2013a), Balathandayutham and Sritharan (2013b), Balathandayutham and Sritharan (2013c), Balathandayutham and Sritharan (2013d), Balathandayutham and Sritharan (2014a), Balathandayutham and Sritharan (2014b), Balathandayutham and Sritharan (2014c). It was explored in United Kingdom that only a few researches had been done to know about the wants and needs of the consumers in the context of the interests and preferences for housing Mills (2000). This paves the way to a gap being developed between the expectations of the consumers and the perceptions of the developers, which ultimately leads to dissatisfaction of the consumers Balathandayutham (2017), Balathandayutham (2018), Balathandayutham (2019). Therefore, Ozaki (2002) had stated that the researchers have to pay attention to the challenges faced in the context of housing, in order to bridge the research gap in this context. The examination of the perception of the consumers regarding the factors which 
affect their buying behaviour has to be done by the scholars. The study in this regard is essential as such studies may create awareness for the developers of real estate for the satisfaction of the wants and needs of the customers Daly et al. (2003),Gibler and Nelson (2003), Opoku and Abdul-Muhmin (2010), Balathandayutham and Sritharan (2020a), Balathandayutham and Sritharan (2020b).

\section{NEED FOR THE STUDY}

It becomes important for the marketers and developers of real estate to become aware of the consumer perception regarding housing so as to predict their behaviour in buying of housing structure. The consumers focus on the things they buy, place of purchase, purchasing time and the reason of purchasing houses. The developers of housing have to pay attention to all the aspects of buying a house by the customers, i.e., before, during after buying, in order to offer reasonable and adequate services to their customers. It is an essential element to study about the perception of the consumers regarding housing, in the real estate business. This is because, the main aim of real estate business is to make and retain customers.

\section{OBJECTIVES}

The main aim of the study is to explore the effect of the perception of the consumers on the apartment purchase in Chennai.

\section{REVIEW OF LITERATURE}

Mansi et al. (2013) had studied about the perception of consumers and the buyer behaviour in the purchase of the residential apartments in New Delhi. The authors had identified the internal as well as the external factors which the consumers consider for the purchase of apartments in New Delhi. The internal features include the facilities and specifications provided by the developers of housing in the area of township. On the other hand, the external features include the loan availability, payment details, builder's brand name, discounts offered etc. the authors had also analysed the disparities in buyer's perception regarding the three essential locations for the apartments in New Delhi (greater Noida, Gurgaon and Noida). The analysis was based on the housing parameters like the opportunities for business, conditions of law \& order, educational facilities, medical facilities etc. the authors had also analysed the disparities in the buyer perception regarding the major three players in real estate, Omaxe group,Unitech and Jaypee Infrastructure. The interviews were held with the sales manager and brokers in real estate. The data needed for the study was collected by the authors using questionnaire. The analysis part of the study was carried out by employing excel and SPSS. the instruments of analysis were ANOVA, test of Tukey-Kramer and factor analysis.

Julius et al. (2016) explored the factors which affected the purchase intention, in the context of housing, of the consumers. The study was carried out at Kota Kinabalu, by the execution of the model theory of buyer behaviour. The construction of houses at Sabah purely depended on the economic features and not according to the interest and preferences of the consumers. It would be beneficial for the housing developers and buyers to understand the factors which contributes to the process of decision-making of the consumers in the market of real estates. Hence, the study shown here had aimed to become aware of the behaviour of consumers regarding the house purchase with the help of the Theory of Buyer Behaviour Model (Perceptual and Output). The main aim of this research study was to investigate the 
effect of housing features on the intentions of house purchase. On the basis of the information collected from 235 working adults, the outcomes showed that the features of housing, finance, housing environment, distance and the superstitious beliefs was seen to have an optimistic relation with the intention of housing purchase.

Jeremy et al. (2018) studied the prediction of consumer perception and its effect on the purchase intention in the context of the market for residential property. The aim of the research was to examine the impacts of perceived value of the customers on the purchase intention of the customers in the field of the market for residential property. The study was done in Malaysia. The design of the study was explanatory. The questionnaire was used to collect the primary data. The respondents were selected through convenience sampling and the sample size of the study was 172 . The data distribution, demographics, reliability and normality were checked with the help of SPSS 22 . The relation between the study variables was explored with the help of regression and Pearson correlation. The findings of the analysis of the data showed that there was a positive relationship of consumer perception on their purchase intention of residential property.

Araloyin and Olatoye (2011) had done an analysis of the consumer perception regarding the service quality in the context of real estate. The study was done regarding the practice of estate agency in the Lagos metropolis of Nigeria. the study was done to create better satisfaction of the consumers and also to improve the service quality of the market for real estate. Questionnaire which was selfadministered were used to collect the data needed for the study. The sample size of the study was 203. The findings showed that the consumers of real estate value the service delivery of the agency of real estate but do not value the agents in real estate. The outcomes of the study showed five main elements of the satisfaction of the consumers in the context of real estate for the purpose of the study. These elements included regular communication, courtesy, offering prompt service, performance of services on time and personal attention. All these elements were found to be responsible for the satisfaction of the consumers.

\section{RESEARCH METHODOLOGY}

The study shows the relation between consumer perception and the purchase intention of the customers regarding the purchase of apartments. The respondents of the study were the customers of flat purchase in Chennai and they were selected through simple random sampling. The sample size of the study was 100 . The data needed for the study is collected through q questionnaire and analysis of the data is done through regression.

\section{ANALYSIS AND INTERPRETATION}

$\begin{array}{ccccc}\mathbf{R} & \text { R Square } & \text { Adjusted R Square } & \text { F } & \text { Sig. } \\ .950(\text { a) } & .903 & .895 & 122.097 & .000(\mathrm{a})\end{array}$

\begin{tabular}{|c|c|c|c|c|c|}
\hline & \multicolumn{2}{|c|}{$\begin{array}{l}\text { Unstandardized } \\
\text { Coefficients }\end{array}$} & \multirow{2}{*}{$\begin{array}{c}\text { Standardized } \\
\text { Coefficients } \\
\text { Beta }\end{array}$} & \multirow[t]{2}{*}{$\mathbf{t}$} & \multirow[t]{2}{*}{ Sig. } \\
\hline & B & Std. Error & & & \\
\hline (Constant) & -.173 & .150 & & 1.148 & .254 \\
\hline $\begin{array}{l}\text { My flat is really good and is the symbol } \\
\text { of social status }\end{array}$ & .134 & .032 & .197 & 4.182 & .000 \\
\hline
\end{tabular}




\begin{tabular}{|c|c|c|c|c|c|}
\hline $\begin{array}{l}\text { The better location of the flat increases } \\
\text { willingness to buy the flat }\end{array}$ & .179 & .054 & .186 & 3.350 & .001 \\
\hline $\begin{array}{c}\text { The lowered flat price will increase the } \\
\text { purchase intention. }\end{array}$ & .181 & .030 & .297 & 6.070 & .000 \\
\hline $\begin{array}{l}\text { Buying a flat will increase wealth in } \\
\text { future. }\end{array}$ & .184 & .044 & .204 & 4.148 & .000 \\
\hline $\begin{array}{l}\text { I am interested in flat because I believe } \\
\text { that the quality control of particular } \\
\text { flat is better. }\end{array}$ & .116 & .039 & .129 & 2.978 & .004 \\
\hline $\begin{array}{l}\text { I visited the flat sales centre many } \\
\text { times because the promotion of the } \\
\text { company has expressed better } \\
\text { opinions regarding the flat. }\end{array}$ & .084 & .028 & .118 & 3.002 & .003 \\
\hline $\begin{array}{l}\text { The better quality of external } \\
\text { environments motivates me to buy this } \\
\text { flat. }\end{array}$ & .167 & .039 & .194 & 4.242 & .000 \\
\hline
\end{tabular}

The above table revealed a positive coefficient, which means that among all the statements of consumer perception were influence on the purchase intention of flat purchasers in Chennai. There was a positive relation found between consumer perception and purchase intention. $R$ value of this study was 0.903 and significant value of the study was 0.00 . Findings show that the purchase intention was highly influenced by the consumer perception.

\section{CONCLUSION}

The knowledge and the information regarding the consumer perception are important for the development of successful strategies of marketing as such information helps to create and withhold valuable customers and also to build relationship with the customers. This study will be useful for the scholars to make further studies in this regard and also for the housing developers to understand the perception of the customers regarding housing and frame service strategies in housing accordingly. Findings show that the purchase intention was highly influenced by the consumer perception.

\section{REFERENCES}

Araloyin, F. M. and Olatoye O. (2011) An analysis of real estate consumers' perception of service quality in estate agency practice in Lagos metropolis, Nigeria Journal of Economics and International Finance Vol. 3(3), pp. 139145, March 2011. Retrieved from https://doi.org/10.5897/JEIF.9000006

Balathandayutham, P. \& Sritharan, R. (2012b) Residential Satisfaction : An Empirical Study with Special Focus on Flat Purchase, International Journal of Applied.

Balathandayutham, P. (2016) A study on antecedent and consequences of customer satisfaction in apartment culture at Chennai, International Journal of Management Studies 3, 129-139. Retrieved from https://www.researchgate.net/profile/Balathandayutham-DrP/publication/342834720_International_Journal_of_Management_Studies_ A_STUDY_ON_ANTECEDENT_AND_CONSEQUENCES_OF_CUSTOMER_SATIS FACTION_IN_APARTMENT_CULTURE_AT_CHENNAI_Introduction/links/5f 085826299bf1881610395f/International-Journal-of-Management-Studies- 
A-STUDY-ON-ANTECEDENT-AND-CONSEQUENCES-OF-CUSTOMER-

SATISFACTION-IN-APARTMENT-CULTURE-AT-CHENNAI-Introduction.pdf

Balathandayutham, P. (2017) A study on perceived risk of residential construction companies and its customers, International Journal of Management Studies 4, 181-186. Retrieved from https://www.researchgate.net/profile/Balathandayutham-Dr-

P/publication/342831947_Online2231-2528Vol-IV_Issue-

1/links/5f07fa4f299bf188161027d7/Online2231-2528Vol-IV-Issue-1.pdf

Balathandayutham, P. (2018), A study on the satisfaction of the elderly people in apartment culture, International Journal of Management Studies 5 (1), 3. Retrieved from https://www.researchgate.net/profile/BalathandayuthamDr-

P/publication/342902083_A_Study_on_the_Satisfaction_of_the_Elderly_Peo ple_in_Apartment_Culture/links/5f0cab074585155a55257b7c/A-Study-

on-the-Satisfaction-of-the-Elderly-People-in-Apartment-Culture.pdf

Balathandayutham, P. (2019) Influence of apartment price on residential satisfaction: A study in chennai, International Journal of Research in Computer Application \& Management, Volume no. 9 (2019), issue no. 11 (November), 5-7

Balathandayutham, P., \& Sritharan, R. (2012c) A Study on Real Estate Marketing with Special Reference to Apartment Purchase, Selp Journal of Social Science 3 (12), 431-435. Retrieved from https://www.researchgate.net/profile/Balathandayutham-DrP/publication/342901835_A_STUDY_ON_REAL_ESTATE_MARKETING_WIT H_SPECIAL_REFERENCE_TO_APARTMENT_PURCHASE/links/5f0c9d2f299 bf10744533d86/A-STUDY-ON-REAL-ESTATE-MARKETING-WITHSPECIAL-REFERENCE-TO-APARTMENT-PURCHASE.pdf

Balathandayutham, P., \& Sritharan, R. (2012a) Marketing Strategies for consumer house buying behaviour, Revitalising Global Business, 994-995

Balathandayutham, P., \& Sritharan, R. (2013a) A Focus on Factors Influencing Residential Satisfaction, Review Journal of Philosophy and Social Science 38 (2), 123-132

Balathandayutham, P., \& Sritharan, R. (2013b), Detailed Investigation of Residential Satisfaction in Apartment"s Management Service, International Journal of Research in Commerce 3 (9), 98-99

Balathandayutham, P., \& Sritharan, R. (2013c) A Study on Role of Management Graduate's Services in Real Estate Business, M.S.R Journal of Managment 1 (2), 116-118. Retrieved from https://www.researchgate.net/profile/Balathandayutham-DrP/publication/342902040_A_STUDY_ON_ROLE_OF_MANAGEMENT_GRAD UATE'S_SERVICES_IN_REAL_ESTATE_BUSINESS/links/5f0ca33fa6fdcca32a e69a51/A-STUDY-ON-ROLE-OF-MANAGEMENT-GRADUATES-SERVICESIN-REAL-ESTATE-BUSINESS.pdf

Balathandayutham, P., \& Sritharan, R. (2013d) Service quality survey in apartment industry: a study on residential satisfaction among urban resident. IISRO Multi-conferences proceeding. Retrieved from https://www.researchgate.net/profile/Balathandayutham-DrP/publication/342831707_Service_quality_survey_in_apartment_industry_ a_study_on_residential_satisfaction_among_urban_residents/links/5f07f40 2299bf188161026d8/Service-quality-survey-in-apartment-industry-astudy-on-residential-satisfaction-among-urban-residents.pdf 
Balathandayutham, P., \& Sritharan, R. (2014a) A Study on the Residential Satisfaction among the Elderly in Chennai, International Journal of Research in Management Studies (IJRMS) 6 (1), 6-9. Retrieved from https://www.researchgate.net/profile/Balathandayutham-Dr-

P/publication/342902091_A_study_on_the_residential_satisfaction_among _the_elderly_in_Chennai/links/5f0cacbe92851c38a51a6a3e/A-study-on-

the-residential-satisfaction-among-the-elderly-in-Chennai.pdf

Balathandayutham, P., \& Sritharan, R. (2014b) Factorial Study on Residential Satisfaction of Apartment Residents, Sankhya International Journal of Management and Technology 3 (II (a)), 79-80. Retrieved from https://www.researchgate.net/profile/Balathandayutham-Dr-

P/publication/342834895_FACTORIAL_STUDY_ON_RESIDENTIAL_SATISF ACTION_OF_APARTMENT_RESIDENTS/links/5f08618445851550509a35b a/FACTORIAL-STUDY-ON-RESIDENTIAL-SATISFACTION-OF-APARTMENTRESIDENTS.pdf

Balathandayutham, P., \& Sritharan, R. (2014c) A Study on Influence of Service Quality on Apartment satisfaction in Chennai, Tamilnadu, M-Infiniti Journal of Management 1 (3), 1-6

Balathandayutham, P., \& Sritharan, R. (2020a) Factors Influencing Of Purchase Behavior: A Study Conducted Among The Purchasers of Flat In Chidambaram, International Journal of Research-Granthaalayah 8 (7), 330334.

Retrieved from https://doi.org/10.29121/granthaalayah.v8.i7.2020.726

Balathandayutham, P., \& Sritharan, R. (2020b) Retail Bank Atm's Service Quality Affecting Customer Satisfaction: An Attempt To Draw The Attention, International Journal of Engineering Technologies and Management Research $7 . \quad$ Retrieved from https://doi.org/10.29121/ijetmr.v7.i7.2020.739

Daly, J., Gronow, S., Jenkins, D., \&Plimmer, F. (2003). Consumer behaviour in the valuation of residential property: A comparative study in the UK, Ireland and Australia. Property Management, 21(5), 295-314. Retrieved from https://doi.org/10.1108/02637470310508653

Gibler, K. M., \& Nelson, S. L. (2003). Consumer Behavior Applications to Real Estate Education. Journal of Real Estate Practice and Education, 6(1), 63-89. Retrieved from https://doi.org/10.1080/10835547.2003.12091585

Jeremy Tsang Tsun Hoe, Omkar Dastane and Karthik Selvaraj (2018) Predicting consumer perception and its impact on purchase intention for residential property market ; Journal of Technology Management and Business (ISSN: 2289-7224) Vol 5, No 2, 2018. Retrieved from https://doi.org/10.30880/jtmb.2018.10.01.019

Julius Chia, Amran Harun, Abdul Wahid MohdKassim, David Martin and NoreinaKepal (2016) understanding factors that influence house purchase intention among consumers in Kota Kinabalu: an application of buyer behavior model theory; Journal of Technology Management and Business (ISSN: 2289-7224) Vol 03, No 02, 2016. Retrieved from https://penerbit.uthm.edu.my/ojs/index.php/jtmb/article/view/1466/0

Maclennan, D. (2002). The Review of Scotland's Cities. Edinburgh: Her Majesty's Stationery Office.

Mansi Misra, GaganKatiyar and Ajoy Kumar Dey (2013) Consumer perception and buyer behaviour for purchase of residential apartments in NCR; 
International Journal of Indian Culture and Business Management6(1):56 68. Retrieved from https://doi.org/10.1504/IJICBM.2013.050714

Mills, T. (2000). Customer care - are you doing enough? Housebuilder, October. Ozaki, R.(2002). Housing as a reflection of culture: Privatised living and privacy in England and Japan. Housing Studies, 17, 209-227. Retrieved from https://doi.org/10.1080/02673030220123199

Opoku, R. A., \& Abdul-Muhmin, A. G. (2010). Housing preferences and attribute importance among low-income consumers in Saudi Arabia. Habitat International, 34, 219-227. Retrieved from https://doi.org/10.1016/j.habitatint.2009.09.006

Swartz, T. \& Brown, S. (1989). A Gap analysis of professional service quality. Journal of Marketing, 53(2), 92-98. Retrieved from https://doi.org/10.1177/002224298905300207 